Економічні науки: збірник наукових праиь Луиького національного технічного університету. - Серія "Регіональна економіка". - Випуск 16 (63). - Редкол.: відп. ред. д.е.н., професор Л.Л. Ковальська - Луцьк : ІВВ Луциького НТУ, 2019. -173 с.

УДК 332.1:332.83

Кривов'язюк І.В., к.е.н., професор

Заблоцька І.Л.

Луцький національний технічний університет

\title{
СТАН ЖИТЛОВОГО БУДІВНИЦТВА В РЕГІОНАХ УКРАЇНИ
}

В статті актуалізовано проблематику дослідження сфери житлового будівництва в регіонах України. На основі результатів аналізу змісту публікацій вчених сучасності розкрито пріоритетні напрямки досліджень у визначенні стану житлового будівництва в регіонах України. Вивчено стан житлового будівництва в регіонах України. Систематизовано проблеми житлового будівництва в регіонах України. Запропоновано напрямки покращення стану житлового будівництва.

Ключові слова: житлове будівництво, регіональна нерівність, забезпечення населення житлом, соціально-економічна стабільність, регіони України. 

університету. - Серія "Регіональна економіка". - Випуск 16 (63). - Редкол.: відп. ред. д.е.н., професор Л.Л. Ковальська - Луцьк : ІВВ Луцького НТУ, 2019. -173 с.

\section{Kryvovyazyuk I.V., Zablotska I.L. STATE OF RESIDENTIAL CONSTRUCTION IN REGIONS OF UKRAINE}

Research of the state of residential construction in regions of the country has always been a crucial task which is aimed at finding ways to solve one of the most acute socio-economic problems in the Ukrainian economy. The state of residential construction directly affects the level of socio-economic stability in regions, determines the future development of the country's economy. Adequate housing is a top priority which is under the control of the government and regional authorities.

Analysis of the dynamics of capital investment in housing in regions of Ukraine has showed that positive changes of this indicator during 2012-2017 can be observed in Kiev region only while for all other oblasts and the city of Kiev unbalanced growth can be observed. Problems accompanying changes in capital investment in housing in regions include lack of adequate state support for the housing sector, various vectors of local regional policy, military conflict in eastern part of Ukraine, lack of funds to meet existing demand for housing, stragnation on real estate market, lack of proper working conditions for foreign developers in Ukraine.

Analysis of the dynamics on the area of new residential construction in regions of Ukraine in 2012-2017 has showed that positive changes of this indicator are typical for Zhytomyr region and the city of Kiev. Ivano-Frankivsk, Kyiv, Lviv, Odesa and Kharkiv regions, as well as Kyiv, are characterized by the largest amount of newly build houses taken into use. The problems that characterize changes in the area of new housing in regions of Ukraine include the lack of the necessary amount of investment into the activities of developers, insufficient production capacity of developers, some regions have poor permitting procedures, concentration of population in regions with high wages should be taken into account.

It has been established that the housing stock is growing year after year in Ukraine. The largest amount of housing stock is in Dnipropetrovsk, Kharkiv, Kyiv and Lviv regions, Kyiv, the smallest is in Chernihiv, Sumy, Ternopil, Rivne, Mykolaiv, Kirovohrad, Kherson and Chernivtsi regions. Problems accompanying changes in the housing stock in regions of Ukraine include the significant proportion of the demolition of the housing stock, insufficient housing stock with adequate communications, lack of funds to update the housing stock in regions, the absence of a strategy to increase housing stock depending on the state of the economy of the country.

The problems identified are organized into such categories as organizationaleconomic, socio-economic, political-legal, national security, production-technical, environmental and financial-economic. The most important are the problems included into financial and economic subsystem, which can be observed in the analysis of each area of study of state of residential construction in regions.

The current state of residential construction in the regional context needs to highlight the following areas of its improvement: improvement of the strategy of development of residential construction in Ukraine and development of regional 
Економічні науки: збірник наукових праџь Луцького національного технічного університету. - Серія "Регіональна економіка". - Випуск 16 (63). - Редкол.: відп. ред. д.е.н., професор Л.Л. Ковальська - Луцьк : ІВВ Луцького НТУ, 2019. -173 с.

programs of its comprehensive support; promotion of residential construction; formation of investment attractiveness in regions.

Key words: residential construction, regional inequality, housing, socioeconomic stability, regions of Ukraine.

Кривовязюк И.В., Заблоцкая И.Л.

\section{СОСТОЯНИЕ ЖИЛИЩНОГО СТРОИТЕЛЬСТВА В РЕГИОНАХ УКРАИНЫ}

В статье актуализирована проблематика исследования сферы жилищного строительства в регионах Украины. На основе результатов анализа содержания публикаций ученых современности раскрыто приоритетные направления исследований в определении состояния жилищного строительства в регионах Украины. Изучено состояние жилищного строительства в регіонах Украины. Систематизированы проблемы жилищного строительства в регіонах Украины. Предложены направления улучшения состояния жилищного строительства.

Ключевые слова: жилищное строительство, региональное неравенство, обеспечение населения жильем, социально-экономическая стабильность, регионы Украины.

\section{Постановка проблеми у загальному вигляді та іï} зв'язок 3 важливими науковими й практичними завданнями. Проблематика вивчення стану житлового будівництва в регіонах України має незаперечну актуальність через недостатню забезпеченість житловою площею населення, нерівномірне розміщення будівельних організацій в межах регіонів, різний попит на житло в регіонах України, різні можливості на рівні регіональних органів влади щодо забезпечення цього попиту, й у т.ч. фінансово-економічні. Питання забезпечення населення житлом має тісний зв'язок 3 вирішенням існуючих соціально-економічних проблем в країні, виходячи 3 проблеми переселенців, забезпечення малозабезпечених верств населення, військовослужбовців тощо. Стан житлового будівництва безпосередньо впливає на рівень соціально-економічної стабільності в регіонах, визначає майбутній розвиток економіки країни в цілому. Належне забезпечення житлом $є$ першочерговим завданням, яке перебуває на контролі уряду та регіональних органів влади. 
Економічні науки: збірник наукових праџь Луцького національного технічного університету. - Серія "Регіональна економіка". - Випуск 16 (63). - Редкол.: відп. ред. д.е.н., професор Л.Л. Ковальська - Луцьк : ІВВ Луцьького НТУ, 2019. -173 с.

Аналіз останніх досліджень і публікацій. Аналіз наукових публікацій вчених показав, що дослідження стану житлового будівництва, як стверджує Н. Бугайчук [1], може здійснюватись шляхом моніторингу розвитку житловокомунальної інфраструктури України, доводячи важливість його результатів для оцінки рівня економічної безпеки держави. На нашу думку, слід вести мову не стільки про економічну, скільки про соціально-економічну складову економічної безпеки країни, вивчаючи дану проблему на регіональному рівні, що особливо актуально в умовах військових дій на сході країни. Натомість, на думку В. Зайця [2], дана проблематика, попри зростання деяких показників житлової забезпеченості, також вимагає вивчення житлових умов населення із врахуванням їх відповідності європейським нормам. В роботі $\mathrm{B}$. Кравченко [4] увага зосереджується на дослідженні динамізації показників житлового фонду України, а житлова проблема відноситься до числа тих, які потребують активної державної підтримки для іiі розв'язання. А. Ляшева вивчає причини регіональної нерівності та розвитку житлової сфери в умовах такої нерівномірності, виділяючи Київську, Львівську, Івано-Франківську, Волинську та Хмельницьку області як такі, що характеризують найбільші темпи будівництва житла в Україні. Нерівномірність розвитку житлової сфери авторка пов'язує 3 такими факторами як «механізми розподілу землі, перетворення житла на товар та об'єкт інвестування, а також знищення альтернатив ринковим механізмам виробництва, тобто державного будівництва» [7], що є досить слушною думкою. Н. Петрищенко, В. Андріянов та Г. Рижова, аналізуючи динамізм змін обсягів виконаних будівельних робіт, прийняття в експлуатацію житла (нове будівництво), його розподілу за видами будівель, приходять до висновку, що «негативними факторами, що привели до скорочення попиту та пропозицій на ринку, відзначено скорочення доходів населення, малого та середнього бізнесу, нестабільність курсу гривні, складний політико-економічний стан країни, відсутність інвестиційних ресурсів у забудовників, ... а основною умовою формування сучасного ринку житлової 
Економічні науки: збірник наукових праџь Луцького національного технічного університету. - Серія "Регіональна економіка". - Випуск 16 (63). - Редкол.: відп. ред. д.е.н., професор Л.Л. Ковальська - Луцьк : ІВВ Луцького НТУ, 2019. -173 с.

нерухомості та виходу його зі стану депресивної стабільності повинно бути встановлення балансу між платоспроможністю населення та ціновою політикою забудовників» [8, с. 138]. Проте, важливу роль має відігравати у цьому й регіональна політика. Д. Харечко й М. Куйбіда [9] вказують про необхідність державного регулювання реалізації житлових прав громадян України. Але не менш важливим питанням $\epsilon$ визначення світової практики державного регулювання інвестиційної привабливості житлової сфери [6]. Окремої уваги заслуговує й питання вивчення напрямків стимулювання фінансово-економічних механізмів розвитку житлового будівництва в регіоні [5]. Недостатнє вивчення стану житлового будівництва саме в регіонах у працях вчених сучасності вимагає поглибленого дослідження цієї проблематики.

Цілі статті. Метою дослідження є аналіз і систематизація проблем житлового будівництва в регіонах України задля встановлення напрямків покращення існуючого стану.

Виклад основного матеріалу. Для дослідження сучасного стану житлового будівництва в регіонах України доцільним $\epsilon$ аналізування динамізму капітального інвестування житлового будівництва, площі нового житлового будівництва на початок його здійснення, а також вивчення змін житлового фонду в регіонах України. Також важливим моментом $\epsilon$ визначення проблем житлового будівництва в регіонах України та подальша їх систематизація з метою подальшого розроблення напрямків покращення стану житлового будівництва на рівні регіонів.

Для здійснення житлового будівництва першочергове значення має обсяг капітальних інвестицій, спрямований на покращення існуючого стану із забезпечення житлом населення країни. Зміни в обсягах капітальних інвестицій, спрямованих на створення житлових об’єктів у регіонах України в період 2012-2017 рр. представлено в таблиці 1. 
Економічні науки: збірник наукових праџь Луцького національного технічного університету. - Серія "Регіональна економіка". - Випуск 16 (63). - Редкол.: відп. ред. д.е.н., професор Л.Л. Ковальська - Луцьк : ІВВ Луцьккого НТУ, 2019. -173 с.

Таблиця 1

Динамізм капітального інвестування житлового будівництва в регіонах України в період 2012-2017 рр., млн. грн. [3, с. 10]

\begin{tabular}{|l|c|c|c|c|c|c|}
\hline Регіони країни & 2012 p. & 2013 p. & 2014 p. & 2015 p. & 2016 p. & 2017 p. \\
\hline Вінницька & 1028 & 1256 & 780 & 1277 & 1110 & 1299 \\
\hline Волинська & 889 & 710 & 812 & 1315 & 1440 & 1706 \\
\hline Дніпропетровська & 953 & 1025 & 927 & 1422 & 1481 & 1223 \\
\hline Донецька & 1715 & 1738 & 673 & 114 & 179 & 275 \\
\hline Житомирська & 461 & 503 & 470 & 865 & 684 & 783 \\
\hline Закарпатська & 1059 & 1083 & 1141 & 1494 & 1232 & 1863 \\
\hline Запорізька & 775 & 471 & 261 & 337 & 457 & 355 \\
\hline $\begin{array}{l}\text { Івано- } \\
\text { Франківська }\end{array}$ & 1490 & 1679 & 2419 & 2511 & 2124 & 2342 \\
\hline Київська & 4116 & 4446 & 4491 & 6135 & 7061 & 8429 \\
\hline Кіровоградська & 311 & 298 & 163 & 339 & 162 & 233 \\
\hline Луганська & 431 & 458 & 101 & 138 & 114 & 202 \\
\hline Львівська & 2316 & 2262 & 3026 & 4030 & 3950 & 4632 \\
\hline Миколаївська & 341 & 357 & 267 & 493 & 497 & 383 \\
\hline Одеська & 2439 & 1733 & 1540 & 1362 & 1687 & 2534 \\
\hline Полтавська & 675 & 910 & 742 & 1112 & 962 & 1420 \\
\hline Рівненська & 832 & 958 & 870 & 1200 & 1357 & 1417 \\
\hline Сумська & 641 & 481 & 468 & 572 & 521 & 494 \\
\hline Тернопільська & 1116 & 1045 & 682 & 1480 & 1069 & 1540 \\
\hline Харківська & 1579 & 1500 & 1142 & 1642 & 2252 & 3393 \\
\hline Херсонська & 386 & 362 & 282 & 345 & 245 & 335 \\
\hline Хмельницька & 863 & 1111 & 1579 & 3035 & 3619 & 2934 \\
\hline Черкаська & 405 & 391 & 412 & 933 & 737 & 1011 \\
\hline Чернівецька & 1333 & 1291 & 754 & 1485 & 846 & 977 \\
\hline Чернігівська & 625 & 613 & 398 & 705 & 500 & 540 \\
\hline м. Київ & 7478 & 9447 & 8777 & 11269 & 10579 & 13052 \\
\hline Разом & 34256 & 36129 & 33177 & 45610 & 44865 & 53372 \\
\hline
\end{tabular}

Аналіз динамізму капітального інвестування житлового будівництва в регіонах України показав, що позитивні зміни 
Економічні науки: збірник наукових праџь Луцького національного технічного університету. - Серія "Регіональна економіка". - Випуск 16 (63). - Редкол.: відп. ред. д.е.н., професор Л.Л. Ковальська - Луцьк : ІВВ Луиького НТУ, 2019. - 173 с.

даного показника впродовж усього періоду, а саме 2012-2017 pp., характеризують лише Київську область, для усіх інших областей та м. Київ - характерне розбалансоване зростання. Разом 3 тим, найбільші обсяги капітального інвестування в цілому періоді характеризують Вінницьку, Закарпатську, ІваноФранківську, Київську, Львівську, Одеську, Тернопільську, Херсонську області та м. Київ.

Якщо взяти до уваги значення показника капітальні інвестиції у житлове будівництво в розрахунку на одну особу по регіонах у 2017 році, то в число регіонів 3 показником вище середнього по України, потрапляють Київська область (4848,3 грн. на одну особу), м. Київ (4518,2 грн.), Хмельницька (2298,2 грн.), Львівська (1843,0 грн.), Івано-Франківська $(1702,4$ грн.), Волинська $(1645,1 \quad$ грн.), Закарпатська (1483,5 грн.), Тернопільська (1463 грн.) та Харківська області (1265,2 грн.) [3, с. 14].

Визначено, що до кола проблем, які супроводжують зміни обсягів капітального інвестування житлового будівництва в регіонах, найчастіше відносять: відсутність належної державної підтримки сфери житлового будівництва, різні вектори регіональної політики на місцях, військовий конфлікт на сході України, нестача коштів для задоволення наявного попиту на житло серед населення, стагнація ринку житлової нерухомості, відсутність створення умов для роботи в Україні іноземних девелоперів i, водночас, низька інвестиційна привабливість економіки України.

Разом 3 тим, постійне освоєння капітальних інвестицій у житлове будівництво в усіх регіонах України виступає потужною основою введення площ нового житла (таблиця 2).

Аналіз динамізму площі нового житлового будівництва в регіонах України в період 2012-2017 рр. показав, що позитивні зміни даного показника характеризують Житомирську область та м. Київ. Найбільші обсяги введення нових площ стабільно характеризують Івано-Франківську, Київську, Львівську, Одеську та Харківську області, а також м. Київ. 
Економічні науки: збірник наукових праџь Луцьького національного технічного університету. - Серія "Регіональна економіка". - Випуск 16 (63). - Редкол.: відп. ред. д.е.н., професор Л.Л. Ковальська - Луцьк : ІВВ Луцьккого НТУ, 2019. -173 с.

Таблиця 2 Динамізм площі нового житлового будівництва на його початок в регіонах України в період 2012-2017 рр., тис. м² [3, с. 19]

\begin{tabular}{|l|c|c|c|c|c|c|}
\hline \multicolumn{1}{|c|}{ Регіони країни } & $2012 \mathrm{p}$. & $2013 \mathrm{p}$. & $2014 \mathrm{p}$. & $2015 \mathrm{p}$. & $2016 \mathrm{p}$. & $2017 \mathrm{p}$. \\
\hline Вінницька & 194 & 91 & 144 & 259 & 384 & 246 \\
\hline Волинська & 21 & 37 & 91 & 183 & 200 & 129 \\
\hline Дніпропетровська & 40 & 65 & 34 & 174 & 349 & 271 \\
\hline Донецька & 129 & 132 & 18 & $\ldots$ & $\ldots$ & $\ldots$ \\
\hline Житомирська & 2 & 12 & 40 & 49 & 162 & 128 \\
\hline Закарпатська & 35 & 60 & 52 & 47 & 53 & 49 \\
\hline Запорізька & 7 & 7 & 8 & 41 & 105 & 12 \\
\hline Івано-Франківська & 375 & 188 & 372 & 295 & 290 & 418 \\
\hline Київська & 260 & 199 & 662 & 463 & 1271 & 1066 \\
\hline Кіровоградська & 2 & 6 & $\ldots$ & 24 & 44 & 7 \\
\hline Луганська & 4 & 23 & 2 & $\ldots$ & $\ldots$ & 11 \\
\hline Львівська & 249 & 146 & 278 & 589 & 988 & 1354 \\
\hline Миколаївська & 60 & 23 & 32 & 42 & 95 & 174 \\
\hline Одеська & 319 & 246 & 279 & 623 & 1251 & 1052 \\
\hline Полтавська & 119 & 95 & 58 & 158 & 162 & 167 \\
\hline Рівненська & 13 & 69 & 35 & 92 & 92 & 173 \\
\hline Сумська & 60 & 65 & 112 & 158 & 119 & 26 \\
\hline Тернопільська & 182 & 94 & 206 & 354 & 119 & 204 \\
\hline Харківська & 184 & 138 & 226 & 366 & 529 & 1003 \\
\hline Херсонська & 10 & 9 & 14 & 26 & 57 & 19 \\
\hline Хмельницька & 100 & 91 & 404 & 408 & 560 & 292 \\
\hline Черкаська & 28 & $\ldots$ & 58 & 83 & 221 & 127 \\
\hline Чернівецька & 73 & 88 & 78 & 88 & 191 & 131 \\
\hline Чернігівська & 77 & 76 & 90 & 77 & 66 & 81 \\
\hline Київ & 894 & 1124 & 1775 & 1983 & 2706 & 4228 \\
\hline Разом & 3437 & 3084 & 5068 & 6582 & 10014 & 11368 \\
\hline
\end{tabular}

Встановлено, що до кола проблем, які характеризують зміни площі нового житлового будівництва в регіонах України, віднесено: відсутність необхідного обсягу інвестування 
Економічні науки: збірник наукових праџь Луцького національного технічного університету. - Серія "Регіональна економіка". - Випуск 16 (63). - Редкол.: відп. ред. д.е.н., професор Л.Л. Ковальська - Луцьк : ІВВ Луцьккого НТУ, 2019. -173 с.

діяльності забудовників, недостатні виробничі потужності компаній-забудовників, в окремих регіонах - тривалий час на виділення земель під житлову забудову (дозвільні процедури), концентрація населення в регіонах 3 високою заробітною платою i, як наслідок, їх перенавантаження, неможливість задовольнити потребу у житлі.

Загальна динаміка житлового фонду в регіонах України в досліджуваному періоді представлена в таблиці 3. Результати аналізу показали, що по Україні житловий фонд із року в рік зростає, що на фоні скорочення чисельності населення країни свідчить про збільшення житлової площі, яка припадає на одну особу. Найбільші обсяги житлового фонду припадають на промислово розвинені регіони (Дніпропетровську, Харківську, Київську та Львівську області, а також м. Київ), найменші - на Чернігівську, Сумську, Тернопільську, Рівненську, Миколаївську, Кіровоградську, Херсонську, Волинську та Чернівецьку області.

Визначено, що до кола проблем, які супроводжують зміни житлового фонду в регіонах України, відносять: значна частка зносу житлового фонду, а також фонду, що підлягає знесенню чи заміні через завершення строків його експлуатації, недостатня забезпеченість житлового фонду відповідними комунікаціями, нестача коштів для оновлення житлового фонду в регіонах, відсутність стратегії нарощування житлового фонду залежно від стану економіки країни.

Виділені проблеми житлового будівництва в регіонах України доцільно систематизувати наступним чином: організаційно-економічні, соціально-економічні, політикоправові, національної безпеки, виробничо-технічні, екологічні та фінансово-економічні. Найбільш вагому групу складають проблеми такої підсистеми як фінансово-економічні, які присутні при аналізі кожного з напрямків дослідження стану житлового будівництва в регіонах. 
Економічні науки: збірник наукових праџь Луцького національного технічного університету. - Серія "Регіональна економіка". - Випуск 16 (63). - Редкол.: відп. ред. д.е.н., професор Л.Л. Ковальська - Луцьк : ІВВ Луцького НТУ, 2019. -173 с.

Таблиця 3 Динамізм житлового фонду в регіонах України в період 2012-2017 pp., тис. м² [3, с. 59]

\begin{tabular}{|l|c|c|c|c|c|c|}
\hline \multicolumn{1}{|c|}{ Регіони країни } & 2012 p. & 2013 p. & 2014 p. & 2015 p. & 2016 p. & 2017 p. \\
\hline Вінницька & 44349 & 45709 & 46236 & 46778 & 47409 & 47621 \\
\hline Волинська & 22637 & 22818 & 23112 & 23364 & 23891 & 24362 \\
\hline Дніпропетровська & 79074 & 78141 & 78892 & 78931 & 78031 & 77297 \\
\hline Донецька & 101950 & 103508 & 50591 & 51242 & 51398 & 51539 \\
\hline Житомирська & 33585 & 33610 & 33629 & 33743 & 33734 & 33791 \\
\hline Закарпатська & 29354 & 29574 & 30141 & 30414 & 30643 & 31008 \\
\hline Запорізька & 41075 & 40125 & 40982 & 40935 & 40858 & 40925 \\
\hline Івано-Франківська & 34065 & 34417 & 34941 & 35415 & 36242 & 37027 \\
\hline Київська & 57034 & 57706 & 59245 & 60549 & 62038 & 62756 \\
\hline Кіровоградська & 24729 & 24749 & 24770 & 24833 & 25196 & 25248 \\
\hline Луганська & 55322 & 54978 & 17656 & 17808 & 18820 & 18774 \\
\hline Львівська & 55847 & 56247 & 57323 & 57414 & 58161 & 59192 \\
\hline Миколаївська & 25966 & 25897 & 25841 & 25795 & 25753 & 25744 \\
\hline Одеська & 53411 & 53148 & 53402 & 53421 & 53612 & 56319 \\
\hline Полтавська & 36811 & 36480 & 36374 & 36327 & 36151 & 36115 \\
\hline Рівненська & 24903 & 24572 & 25253 & 25545 & 25866 & 25893 \\
\hline Сумська & 27939 & 27980 & 28119 & 28217 & 28266 & 28345 \\
\hline Тернопільська & 25911 & 26121 & 26576 & 27092 & 27403 & 27744 \\
\hline Харківська & 64891 & 64700 & 65285 & 65269 & 65015 & 65116 \\
\hline Херсонська & 25525 & 25464 & 25437 & 25476 & 25411 & 25039 \\
\hline Хмельницька & 33862 & 33730 & 33726 & 34019 & 34618 & 34896 \\
\hline Черкаська & 34244 & 34168 & 34325 & 34363 & 34351 & 34334 \\
\hline Чернівецька & 21214 & 21542 & 21801 & 22139 & 22337 & 22448 \\
\hline Чернігівська & 29983 & 29986 & 29804 & 29817 & 29200 & 29912 \\
\hline Київ & 61598 & 62219 & 62676 & 64880 & 63463 & 63388 \\
\hline Разом & 1045279 & 1047589 & 966137 & 973786 & 977867 & 984833 \\
\hline
\end{tabular}

Результати дослідження показали, що існуючий стан житлового будівництва в регіональному розрізі потребує виділення наступних напрямків його покращення: 
Економічні науки: збірник наукових праџь Луцького національного технічного університету. - Серія "Регіональна економіка". - Випуск 16 (63). - Редкол.: відп. ред. д.е.н., професор Л.Л. Ковальська - Луцьк : ІВВ Луцьького НТУ, 2019. -173 с.

1. Удосконалення стратегії розвитку житлового будівництва України та в межах регіональних програм комплексної підтримки затвердження пріоритетних завдань щодо забезпечення належних умов 3 реалізації інвестиційних намірів забудовників, підтримка структурної перебудови виробничої бази домобудування, спрощення дозвільних i погоджувальних процедур при будівництві житла.

2. Стимулювання житлового будівництва шляхом зниження відсотків за отриманою кредитною лінією як для компаній-забудовників, так i для фізичних осіб, надання державної підтримки, створення умов для реалізації житлових прав громадян.

3. Формування інвестиційної привабливості економіки задля залучення іноземних компаній-девелоперів, які здатні швидко та якісно покрити існуючий незадоволений попит населення країни у житлі.

Висновки. Дослідження стану житлового будівництва в регіонах країни завжди виступає актуальним завданням, яке спрямовано на пошук шляхів розв' язання однієї з найгостріших соціально-економічних проблем в економіці України. Критичний аналіз змісту публікацій вчених сучасності, що дозволив розкрити пріоритетні напрямки досліджень у визначенні стану житлового будівництва в регіонах України, вказує на недостатність вивчення регіональних особливостей розгортання процесу житлового будівництва та визначає необхідність поглиблення досліджень у цьому напрямку.

Вивчення та аналіз стану житлового будівництва в регіонах України показали, що процеси житлового будівництва здійснюються досить динамічно в усіх регіонах. За показниками інвестування житлового будівництва, введення нових площ i збільшення житлового фонду лідерами є Київська, Львівська, Івано-Франківська та Харківська області та м. Київ. Найбільш значимою проблемою у сфері житлового будівництва визначена нестача фінансування. Систематизація визначених у роботі проблем житлового будівництва в регіонах України стала основою розроблення напрямків покращення стану житлового 
Економічні науки: збірник наукових праџь Луцького національного технічного університету. - Серія "Регіональна економіка". - Випуск 16 (63). - Редкол.: відп. ред. д.е.н., професор Л.Л. Ковальська - Луцьк : ІВВ Луцького НТУ, 2019. -173 с.

будівництва, зокрема удосконалення стратегії розвитку, покращення стимулювання житлового будівництва та забезпечення інвестиційної привабливості цієї сфери.

Напрямки подальших досліджень і розвідок слід спрямувати на аналіз та оцінку стану використання фінансовоекономічних механізмів розвитку житлового будівництва та комплексний аналіз умов фінансування розвитку житлового будівництва в регіонах України.

1. Бугайчук Н.В. Моніторинг розвитку житлово-комунальної інфраструктури України у системі оцінювання рівня економічної безпеки держави. Економіка та держава. 2019. № 9. С. 109-114.

2. Заяць В.С. Розвиток житлового будівництва як фактор формування житлових умов населення. Демографія та соиіальна економіка. 2019. № 2 (3). C. $137-151$.

3. Житлове будівництво в Україні у 2012-2017 рр. Статистичний збірник. Київ : Державна служба статистики України, 2018. 61 с.

4. Кравченко В.І. Житлова економіка України: проблеми теорії та практики. Інвестииіi: практика та досвід. 2019. № 15. С. 5-12. DOI: $\frac{10.32702 / 2306-6814.2019 .15 .5}{5.2}$.

5. Кривов'язюк І.В., Заблоцька І.Л. Фінансово-економічні механізми розвитку житлового будівництва в регіоні (За матеріалами Волинської області) Монографія. Луцьк : Надстир'я, 2006. 144 с.

6. Кривов'язюк І.В., Заблоцька І.Л., Нікітін Т.О. Чи інвестиційно привабливі ринки житлової нерухомості інтенсивно зростаючих країн Азії? Ефективна економіка. 2019. № $9 . \quad$ URL: http://www.economy.nayka.com.ua/?op=1\&z=7257 (дата звернення: 14.11.2019). DOI: 10.32702/2307-2105-2019.9.34.

7. Ляшева А. Житло та регіональна нерівність. Чому в українських містах і селах некомфортно жити? Спільне. Журнал соціальної політики. 29 липня 2019. (дата звернення: 14.11.2019). URL: https://commons.com.ua/uk/zhitlo-ta-regionalna-nerivnist/.

8. Петрищенко Н.А., Андріянов В.С., Рижова Г. Р. Дослідження ринку нерухомості в Україні. Інфраструктура ринку. 2018. Випуск 25. С. 135-139.

9. Харечко Д., Куйбіда М. Державне регулювання реалізації житлових прав громадян України. Демократичне врядування. Науковий вісник. 2016. Вип. 16/17. http://lvivacademy.com/vidavnitstvo_1/visnyk16/fail/Kharechko,Kujbida.pdf. 